\title{
Evaluation of effect of Kati basti in spinal anaesthesia induced low backache
}

\author{
Research Article
}

\section{Richa Tripathi ${ }^{1^{*}}$, Tripathi $\mathbf{J S}^{2}$}

\author{
1. PhD Scholar, 2. Professor and HOD, Department of Kayachikitsa, \\ IMS, Banaras Hindu University, Varanasi, U.P. India.
}

\begin{abstract}
Low backache is localized pain between twelfth thoracic vertebrae and fifth lumbar vertebrae. About $60 \%$ population in India suffers with backache at least once in their life. But in the present context we are concerned with backache, which arises, in postoperative cases following spinal anesthesia. We cannot avoid SA because of its tremendous good effects and the ease, which it provides during surgery to both the surgeon and the patient, but backache after SA has become very common problem. According to Ayurveda this type of backache can be considered as Aghat Janya Kati Shoola. The procedure is done at the site between L1 - L4 vertebrae where there is assortment of various structures like Sira, Sandhi, Asthi, Mansa, Snayu etc. including three important Marma named Nitambha, Kukundar and Katikatarun. Objective: To evaluate the efficacy of Kati Basti in spinal anesthesia induced backache. Methods: Kati Basti with Til Taila was performed for fourteen days in thirty patients. Results: The preliminary study yields significant reduction in the symptoms of stiffness, pain, tenderness, lateral flexion, rotation, SLR, fatigue and ADL. In this condition, Kati Basti is the treatment of choice as it provides long-term symptomatic relief and nourishes the traumatized structures and helps them to heal better.
\end{abstract}

Keywords: Kati Basti, Backache.

\section{Introduction}

Low back pain is defined as pain, which is localized between twelfth thoracic vertebrae and fifth lumbar vertebrae (1). It is not a disease or a diagnostic entity. Most of the persons usually experience back pain, which is a chronic illness with a high likelihood of recovery and recurrence. It may be of variable duration. About $60 \%$ population in India suffers with backache once or more than once in their life. Back pain is the second most common symptom following upper respiratory infections for which people visit the doctor.

As with many other clinical conditions, the cause, course and evaluation of back pain are different in different individuals. But in the present context we are concerned with backache, which arises, in postoperative cases following spinal anesthesia. This type of back pain is most commonly uncomplicated mechanical low back pain. The discomfort is mostly localized to lumbosacral area and worsen with stretching, twisting, bending, walking etc. the pain may cause aching in buttocks and thigh and sometimes it may radiate up to the knee. Sometimes the patient may report being awakened from sleep over changing positions.

The frequency of painless surgery or remaining

*Corresponding Author:

Richa Tripathi

$\mathrm{PhD}$. Scholar. Department of Kayachikitsa,

IMS, Banaras Hindu University,

Varanasi, U.P. India,

Email: richa.23oct@gmail.com awake during surgery is increasing now days and so is this long-term side effect. According to Ayurveda this type of backache can be considered as Aghat Janya Kati Shoola (backache due to trauma). Mostly SA is used in surgeries below lower abdomen frequently gynecological and obstetric procedures, and it is observed that 5 out of 10 i.e. about $50 \%$ females experience this pain within a year after surgery. Spinal anesthesia is an accessory procedure accompanying major surgery, which is used only for creating numbness and immobility in lower body. So, technically it doesn't fit in the definition of prerequisite of Shashtra Karma (Operation). Moreover the procedure is done at the site between L1 - L4 vertebrae where there is assortment of various structures like Sira (blood vessels), Sandhi (joints), Asthi (bone), Mansa (muscles), Snayu (tendons) etc. various Marmas are also found nearby. The three important Marma (vital points) are Nitambha, Kukundar and Katikatarun (2).

Any kind of Aghata (trauma) is initially responsible for vitiation of Vata (3), and after that other Dhatu and Dosha are vitiated. The backache may be due to this Aghat Janya Vata Prakop following spinal anesthesia given at the site of L1- L5.

\section{Purpose of the study}

Back pain after SA has become very common problem. We cannot avoid SA because of its tremendous good effects and the ease, which it provides during surgery to both the surgeon and the patient. Although backache is not a disease and just a symptom, but the feeling of pain, discomfort and unease is reducing the quality of health. 
It will be useful for the Panchakarma practitioners to cure the cause and not the symptom and for patients to improve their conditions without using painkillers, which have many side effects and only provide short-term relief.

\section{Objective}

The aim of the present study is to evaluate the efficacy of Kati Basti in spinal anesthesia induced backache.

\section{Methods}

\section{Inclusion criteria}

- Patients having backache following spinal anesthesia developed from one month of postoperative procedure, irrespective of sex.

- Age - 20 yrs to 70 yrs

- Patients suitable for Bahya Snehan (external oleation)

\section{Exclusion criteria}

- Patients having backache due to any cause other than spinal anesthesia

- Patients who are not suitable for Bahya Snehan

- Garbhini (Pregnant women)

- Patients having grievous diseases like Cancer, AIDS etc.

\section{Informed Consent}

Informed consent was taken from all individuals before enrolling them to the trial.

\section{Criteria for assessment}

Effect of therapy was evaluated before and after the treatment by using parameters such of Pain Greenough \& Fraser scoring method, Functional ability - Sugarbaker and Barofsy clinical mobility scale and Functional disability - Oswestry disability assessment questionaire. The standard questionnaire was asked before and after treatment and after follow up i.e. on 1 st, 7 th \& 14th day. Hence, after 14 days the total score was calculated and analyzed as per statistical methods.

\section{Objective criteria}

1. Straight leg raising test.

2. Tenderness

3. Lateral Flexion

4. Rotation

5. SLR

6. ADL

\section{Subjective criteria}
1. Pain
2. Stiffness.
3. Fatigue

\section{Grading:}

\section{Stiffness}
$0 \quad$ No stiffness
1 Sometimes for 5-10 minutes
2 Daily for 10- 30 minutes
3 Daily for 30- 60 minutes
4 Daily more than 1 hour

\section{Pain}

0 No Pain

1 Occasional Pain

2 Mild pain but difficulty in walking

3 Moderate pain and slight difficulty in walking

4 Severe pain with severe difficulty in walking

\section{Tenderness}
0 No Pain
1 Patient says it's paining
2 Patient winces
3 Patient winces and withdraws the part
4 Patient does not allow touching the part

\section{Lateral flexion}
0 Can do lateral flexion easily
1 Can do lateral flexion with difficulty
2 Cannot perform lateral flexion

\section{Rotation}
0 Can rotate easily
1 Rotation with difficulty

2 Cannot rotate

6. S.L.R. Test

$\begin{array}{ll}0 & \text { More than } 90 \\ 1 & 71-90 \text { degree } \\ 2 & 51-70 \text { degree } \\ 3 & 31-50 \text { degree } \\ 4 & \text { Up To 30 degree }\end{array}$

\section{Fatigue}

0 No fatigue

1 Work full time despite fatigue

2 Patient must interrupt work to rest

3 Fatigued at rest

8. ADL
0 All activity without difficulty
1 Most activity but with difficulty
2 Few activity cares for self
3 Little self care mainly on chair \& bed

\section{Material:}

Til Taila: (Sesame Oil)

Til Taila is an edible vegetable oil derived from seeds of Til (Sesame). The oil from the nutrient rich seed is popular in alternative medicine - from traditional massages and treatments to modern day. The oil is popular in Asia and it is one of the earliest known crop-based oils.

Til Taila is purchased from Varanasi Market. Til Taila- $200 \mathrm{ml} /$ day

Masha (black gram) dough for making the boundary for Kati Basti $=100 \mathrm{gm}$. /day

Steel or plastic ring- approx. 10 inches in radius and 2 inches in height.

\section{Method:}

Procedure time $-35 \mathrm{~min}$

Study Design

Prospective, open, randomized trial.

Sample selection: Patients were selected from OPD and IPD of Department of Kaya Chikitsa, IMS, BHU, Varanasi. 
Sample Size: Thirty patients were selected as per inclusion criteria. A special case proforma was prepared and case was studied in detail.

\section{Methodology}

Preoperative: Evacuate stool or urinate before Kati Basti (4) procedure. After the breakfast is Jeerna (digested), the patient is asked to take Kati Basti. Sthanik Snehan (Body massage) and Swedan (Nadi Sweda) are done.

Main procedure: The patient is made to lie down in prone position. Lumbar region is cleaned with a cotton cloth. The steel or plastic ring is put on the affected area of the back or lumbar region. A boundary with black gram dough is made both inside and outside the ring so that the oil is prevented from leakage. Lukewarm Tila
Taila is poured into the boundary with the help of cotton or sponge. The oil is replaced continuously with warm oil and the temperature is maintained throughout the Kati Basti treatment.

\section{Postoperative procedure:}

The oil is removed from the ring and ring is removed from the back. The affected region of back is cleaned with cloth dipped in warm water. The patient is advised to rest in a comfortable posture after the process is finished.

\section{Duration of Kati Basti: 14 Days}

\section{Method Of Data Analysis: -}

The data obtained from the study is compiled, tabulated and analyzed statistically. Statistical analysis is done with paired $t$ test.

\section{Results:}

\begin{tabular}{|l|l|l|l|l|l|l|l|l|}
\hline Symptoms & \multirow{2}{*}{$\begin{array}{l}\text { Group } \\
\text { and n }\end{array}$} & \multicolumn{2}{|l|}{ Mean } & \multirow{2}{*}{$\begin{array}{c}\text { Diff in } \\
\text { mean }\end{array}$} & SD & SE & t & p value \\
\cline { 3 - 4 } & BT & AT & & & & \\
\hline Stiffness & $\mathrm{n}=11$ & 2.091 & 1.000 & 1.091 & 0.302 & 0.090 & 12 & $<0.001$ \\
\hline Pain & $\mathrm{n}=30$ & 1.700 & 1.100 & 0.6 & 0.498 & 0.091 & 5.29 & $<0.001$ \\
\hline Tenderness & $\mathrm{n}=7$ & 1.571 & 0.710 & 0.85 & 0.378 & 0.143 & 6 & $<0.001$ \\
\hline $\begin{array}{l}\text { Lateral } \\
\text { Flexion }\end{array}$ & $\mathrm{n}=30$ & 3.030 & 2.633 & 0.4 & 0.499 & 0.091 & 4.397 & $<0.001$ \\
\hline Rotation & $\mathrm{n}=10$ & 1.600 & 1.000 & 0.600 & 0.516 & 0.163 & 3.678 & $=0.005$ \\
\hline SLR & $\mathrm{n}=9$ & 2.111 & 1.333 & 0.778 & 0.441 & 0.147 & 5.292 & $<0.001$ \\
\hline Fatigue & $\mathrm{n}=30$ & 28.133 & 23.000 & 5.133 & 2.193 & 0.400 & 12.821 & $<0.001$ \\
\hline ADL & $\mathrm{n}=30$ & 16.467 & 20.033 & -3.567 & 1.357 & 0.248 & 14.401 & $<0.001$ \\
\hline
\end{tabular}

\section{Discussion}

The stiffness grade of 2.091 initially was reduced to 1.00 after the trial period. Thus mean difference of 1.091 was observed which was statistically significant. Similarly the mean difference in pain score of 0.6 was observed which is also significant. Mean difference in tenderness was observed to be 0.85 , which is statistically significant. Difference in mean for lateral flexion was observed to be 0.4 , which is statistically significant. In rotation also we got the difference in mean as 0.600 , which is statistically significant. The SLR test shows the difference in mean as 0.778 , which is statistically significant. Difference in mean of the fatigue factor was observed as 5.133, which is statistically significant. The difference in mean for ADL was found to be -3.567 , which was statistically significant.

\section{Mode of action of Kati Basti}

In this specific condition of Spinal anesthesia induced back pain, the structures involved are MarmaKatikatarun, Nitambha (both are Asthi Marma) Kukundhar (Sandhi Marma), along with affected Snayu, Sira and Sandhi. We encounter the Viddha (traumatized) symptoms of these in case of SA induced back pain. Marma Viddha (5) symptoms like different kind of Vata Vedana, Snayu Viddha Laxans like difficulty in movements, Sharir Avayava Avasaad or difficulty in performing the specific functions like Utkshepa (lifting), Apakshepa (bending), Akunchan (flexion), Prasaran (extension) of the body organ, severe pain are present. In this condition, Kati Basti is the treatment of choice as it provides long-term symptomatic relief and nourishes the traumatized structures and help them to heal better. Kati Basti is a kind of Snehayukta Ekanga Swedan (6). Til oil is helpful in Chinna, Bhinna, Chyuta, Utpishta, Mathita, Kshata, Pichchita Bhagna or it is indicated to heal all kind of fractures and traumas. It is Madhura in Rasa and Kashaya Tikta Anurasa, Ushna Veerya, Hima Sparsha 
so, opposite Guna are present which helps it to maintain the Doshik equilibrium in the body. The Til Taila applied over the skin is absorbed through the micro Srotas or channels situated in the Lomakoopa, and undergo Pachana with the help of Bhrajaka Pitta, which is situated in the skin. Warm Til oil used in Kati Basti, pacifies Vata and reduces pain and stiffness. It increases the circulation in the region, as the oil gets deeply absorbed into the skin (moreover it is Rakta Pitta Krita) so nourishes and strengthens the muscles and nerves. It relaxes the surrounding muscles, relieves pain, soreness, tension, restore flexibility and does Prana Pratisthapana at one of the primary sites of Vata i.e. Kati.

\section{Conclusion}

On the basis of the present preliminary study, it may be concluded that Kati Basti is effective in low backache, induced by spinal anesthesia and yields significant results.

\section{References:}

1. Harrison's principles of Internal Medicicine; Volume 1, edited by Casper, Braunwald, Fauci, Hauser, Longo, Jameson, 17th edition, 2005, Pg no. 107

2. Trikamji Yadavaji, Sushruta, Sushruta Samhita Shareera Sthana, Chapter 6 Verse No. 7, edition 2, Chowkhambha Sanskrit Series Varanasi 2002

3. Agnivesha, Charaka, Dridabala, Charaka samhitha,Chikitsa Sthan Chapter 28 Verse No. 17 edition-2004, Shukla Vidyadhar \& Tripathi Ravi dutt, Chaukambha Sanskrit Pratishthan, Delhi, Pg no. 690.

4. Patil Vasant. Principles \& Practice of Panchakarma, Edition 3, Atreya Ayurveda Publications, Ilkal;2010; p. 215

5. Trikamji Yadavaji, Sushruta Samhita of Sushruta, Sutra Sthana, Chapter 25 Verse No. 30, edition 2, Chowkhambha Sanskrit Series Varanasi ;2002

6. Kasture HS, Ayurveda Panchkarma Vijnana, edition 5, Baidyanath Ayurveda Bhavana, 1999, Pg no.473. 